\title{
The Investigation of Effects of Quercetin and Its Combination with Cisplatin on Malignant Mesothelioma Cells In Vitro
}

\author{
A. Demiroglu-Zergeroglu, ${ }^{1}$ B. Basara-Cigerim, ${ }^{1}$ E. Kilic, ${ }^{2}$ and G. Yanikkaya-Demirel ${ }^{3}$ \\ ${ }^{1}$ Department of Biology, Faculty of Science, Gebze Institute of Technology, Gebze 41400, Kocaeli, Turkey \\ ${ }^{2}$ Department of Clinical Biochemistry, Erciyes University, 38039 Kayseri, Turkey \\ ${ }^{3}$ Istanbul Centro Laboratories, 34400 Istanbul, Turkey
}

Correspondence should be addressed to A. Demiroglu-Zergeroglu, ademiroglu@gyte.edu.tr

Received 28 December 2009; Revised 21 March 2010; Accepted 25 March 2010

Academic Editor: Michael Kalafatis

Copyright (C) 2010 A. Demiroglu-Zergeroglu et al. This is an open access article distributed under the Creative Commons Attribution License, which permits unrestricted use, distribution, and reproduction in any medium, provided the original work is properly cited.

\begin{abstract}
Malignant Mesothelioma (MM) is an aggressive and lethal tumour of the serosal surfaces with poor prognosis. In this study, we have investigated the antiproliferative effect of Quercetin (QU) and its combination with Cisplatin (CIS) on SPC212 and SPC111 cell lines. Our experiments showed that QU significantly reduced the proliferation of cell lines, altered the cell cycle distribution, and increased the level of Caspase 9 (C9) and Caspase 3 (C3) in concentration and time-dependent manner. Additionally, the combination of QU + CIS was found more effective when compared with individual treatment of agents.
\end{abstract}

\section{Introduction}

MM is a deadly and difficult disease to treat [1]. Chemotherapeutic agents including Gemcitabine, Imatinib/Gleevec, Gefitinib/Iressa, Bevacizumab/Avastin, Pemeterexed + CIS, and Gemcitabine + CIS are currently used to treat patients of MM [2-6]. However, treatments are not always successful. The bioactivity of flavonoids has been shown in many biological mechanisms related to cancer $[7,8]$. QU is known to possess anticarcinogenic effects, which interfere with the pathways of cancer. QU has been previously reported to have antiproliferative effects on numerous cancers cells including leukemia [9], breast carcinoma [10], colon adenocarcinoma [11], prostate [12], and endometrial cancer [13]. It has also been reported that QU blocks colon, gastric cancer, and human leukemic T cells at G1/S phase of cell cycle [14] and arrests nononcogenic fibroblast and laryngeal, breast, and human acute leukaemia cancer cells at G2/M phase [15-18].

In addition QU induces apoptosis in leukaemia [19], breast [20], ovarian [21], lung [22], oral [23], and colon cancer, [24] and melanoma [25]. CIS is widely used in the treatment of several cancers including head and neck, testicular ovarian, cervical, lung, colorectal, and relapsed lymphoma [26]. CIS and the other platinum drugs are conventionally employed by chemotherapeutic protocols against MM. However, mesothelial cells were found to be intrinsically resistant to CIS [27]. Although the anticarcinogenic effects of CIS and QU have been investigated separately, there is limited data, in the literature examining the combined effects. CIS + QU in combination appear to have a pro-apoptotic effect in HeLa cells [28]. Additionally, QU has been shown to enhance the antiproliferative effect of CIS in leukaemia (HL-60 and L1210) and human laryngeal Hep2 cells [29].

The biological functions of QU combined with CIS on MM cells have not been examined before. In this paper, we have investigated the dose- and time-dependent antiproliferative and apoptotic effects of QU and its combination with CIS on MM cell lines.

\section{Materials and Methods}

2.1. Cell Lines. MM cells were obtained from The Institute of Histology and General Embryology, University of Fribourg, Switzerland. SPC111 cell lines were derived from pleural effusion with mixed histology of male patient and SPC212 cells originate from tumour with mixed histology of female 
patient. All the cells were maintained in RPMI 1640 medium (Invitrogen-Gibco) supplemented with 10\% FBS, 9.2\% $\mathrm{NaHCO}_{3}$ (Sigma-Aldrich), and 1\% penicillin/streptomycin (Invitrogen-Gibco) and incubated at $37^{\circ} \mathrm{C}$ in a humidified atmosphere containing $5 \% \mathrm{CO}_{2}$ in the air.

2.2. Drugs and Reagents. QU (3, 3', 4', 5', 7'-pentahydroxy flavone) and CIS (Cis-diamminedichloroplatinum $\mathrm{Pt}$ (NH3)2Cl2) were purchased from Sigma-Aldrich. Both drugs were dissolved in dimethyl sulfoxide (DMSO) (cell culture tested; Sigma-Aldrich) as 1000-fold concentrated stock solutions and stored at $-20^{\circ} \mathrm{C}$. In order to avoid photoisomerization, all procedures involving drugs were prepared under subdued lighting.

2.3. Assay for Proliferation. One thousand cells per well were seeded in a 96-well plate for 24 hours. Then they were incubated with different concentrations of QU $(5,10,50$, and $100 \mu \mathrm{M})$, CIS $(1,5$, and $10 \mu \mathrm{g} / \mathrm{mL})$, and CIS + QU $(5 \mu \mathrm{g} / \mathrm{mL}$ $+50 \mu \mathrm{M}$ and $10 \mu \mathrm{g} / \mathrm{mL}+50 \mu \mathrm{M})$ for 0-96 hours. Following incubations, a cell titer 96 Aqueous One Solution Cell Proliferation Assay Kit (Promega Madison, W1 USA) was used to measure cell proliferation rate. Two wells of medium without cells were used to give background readings. To each well $20 \mu \mathrm{l}$ of MTS compound was added and the plates were incubated 2 hours before reading the absorbance at $490 \mathrm{~nm}$ with an Elisa reader (Bio-tek instruments.inc).

2.4. Assay for Cell Cycle Distribution. The cells $\left(1 \times 10^{6}\right)$ were plated into $50 \mathrm{~mm}$ diameter Petri dishes and incubated overnight then treated with QU, CIS, and CIS + QU combinations for 24 and 48 hours. At the end of each incubation period, cells were harvested using Trypsin-EDTA (SigmaAldrich) washed with ice-cold 1X PBS and fixed in cold 70\% ethanol. After fixation, cells were washed twice with PBS and incubated in dark for 30 minutes with a staining solution containing $0.1 \%$ Triton X-100/PBS (Sigma-Aldrich) with $1 \mathrm{mg} / \mathrm{mL}$ of RNase A (Sigma-Aldrich) and PI $(20 \mu \mathrm{g} / \mathrm{mL})$ (Sigma-Aldrich) at room temperature. Fluorescence emitted from the PI-DNA complex was quantified after excitation of the fluorescent dye by FACScan flow cytometry (Beckman Coulter Epics XL-MCL).

2.5. Assay for Cell Apoptosis. Both cell lines were initially cultured in Petri dishes for 24 hours. QU $(50 \mu \mathrm{M})$, CIS ( 5 and $10 \mu \mathrm{g} / \mathrm{mL})$, and CIS + QU $(5 \mu \mathrm{g} / \mathrm{mL}+50 \mu \mathrm{M}$ and $10 \mu \mathrm{g} / \mathrm{mL}$ $+50 \mu \mathrm{M})$ were added for further 48 hours. $5 \times 10^{6}$ cells were washed with ice-cold PBS and lysed with caspase cell lysis buffers (Biovision, USA). The lysates were then centrifuged, and the amount of protein was measured by Bicinchoninic acid (BCA) assay at 24 and 48 hour intervals. Samples containing $100 \mu \mathrm{g}$ of total protein were assayed with LEHDpNA as a caspase-9-specific substrate (Biovision, USA) for C9 activity and with DEVD-pNA as a caspase-3-specific substrate (Biovision, USA) for C3 activity. The absorbance was measured at $405 \mathrm{~nm}$ in a microplate reader.

2.6. Statistical Analysis. Results were expressed as mean \pm s.d. of three-five independent experiments and each experiment included duplicate sets. Data was statistically evaluated by one-way ANOVA followed by Dunnett's test. The level of significance was chosen as ${ }^{*} P<.05,{ }^{* *} P<.01$ between control groups and multiple doses, ${ }^{\#} P<.05$ between QU + CIS treatment and CIS alone, and ${ }^{\# \#} P<.05$ between QU + CIS treatment and QU alone. Flow cytometric histograms were generated in linear mode and then analyzed using multicycle DNA software.

\section{Results}

3.1. Effects of $Q U$ and $Q U+C I S$ on Cell Proliferation. To examine the effects of QU, CIS, and CIS + QU on SPC212 and SPC111 cells, exponentially growing cells were treated by QU $(0-100 \mu \mathrm{M})$, CIS $(1-10 \mu \mathrm{g} / \mathrm{mL})$, and CIS $+\mathrm{QU}(5 \mu \mathrm{g} / \mathrm{mL}+50 \mu \mathrm{M}$ and $10 \mu \mathrm{g} / \mathrm{mL}+50 \mu \mathrm{M})$ for 96 hours. The growth inhibition of SPC212 cells was observed at concentrations of QU $\geq 10 \mu \mathrm{M}$ at 72 hours (Figure $1(\mathrm{a})$ ) and CIS $\geq 5 \mu \mathrm{g} / \mathrm{mL}$ (data not shown). However, QU reduced the proliferation of SPC111 cells at concentrations $\geq 50 \mu \mathrm{M}$ at 72 hours (Figure 1(b)). Thus, to prove the ability of QU to enhance anti-proliferative activity of CIS, the optimal dose of QU $(50 \mu \mathrm{M})$ was used for 96 hours. As shown in Figure $2(\mathrm{a}), 5 \mu \mathrm{g} / \mathrm{mL}$ CIS $+50 \mu \mathrm{MQU}$ and $10 \mu \mathrm{g} / \mathrm{mlCIS}+50 \mu \mathrm{MQU}$ applications significantly decreased the proliferation of SPC212 cells when compared with control and the individual agents. The proliferation of SPC111 was also inhibited at same concentrations when compared with control cells, but combined effect was not significantly different from the effects observed in individual treatments on SPC111 cells for 96 hours (Figure 2(b)). In summary, agents inhibited proliferation of SPC212 and SPC111 cells independently or in combination at dose- and time-dependent manner, and combination of CIS + QU resulted in an enhanced antiproliferative activity.

3.2. Effect of Treatments on Cell Cycle Distribution. To investigate effect of QU $(50 \mu \mathrm{M})$, CIS (5 and $10 \mu \mathrm{g} / \mathrm{mL})$, and CIS + QU $(5 \mu \mathrm{g} / \mathrm{mL}+50 \mu \mathrm{M}$ and $10 \mu \mathrm{g} / \mathrm{mL}+50 \mu \mathrm{M})$ on the cell cycle progression of MM cells, we performed a flow cytometric analysis by using PI staining. As shown in Figure 3(b), $50 \mu \mathrm{M}$ dose of QU caused accumulation of SPC212 cells at $S$ phase. However no alteration was observed at the cell cycle profile of SPC111 cells when compared with control cells at 48 hours (Figures 3(c) and 3(d)). Following $5 \mu \mathrm{g} / \mathrm{mL}$ CIS treatments, both cell lines were arrested in S phase for 24 hours (Figures 3(a) and 3(c)), then cells were passed through to G2/M phase in the next 24-hour period (Figures 3(b) and 3(d)). However, when $5 \mu \mathrm{g} / \mathrm{mL}$ CIS was used in combination with $50 \mu \mathrm{MQU}$ both cell lines were arrested and kept in S phase for 48 hours. The percentage of cells reached up to $86 \%, 7 \%$ and $99 \%$ in SPC212 and SPC111 cells, respectively at 48 hours (Figures $3(\mathrm{~b})$ and $3(\mathrm{~d})$ ). This result might suggest that the prolongation of $S$ phase was due to enhanced antiproliferative effect. On the other hand, when CIS dose was increased to $10 \mu \mathrm{g} / \mathrm{mL}$ and applied with $50 \mu \mathrm{M}$ QU, the combination effect was not observed to be 

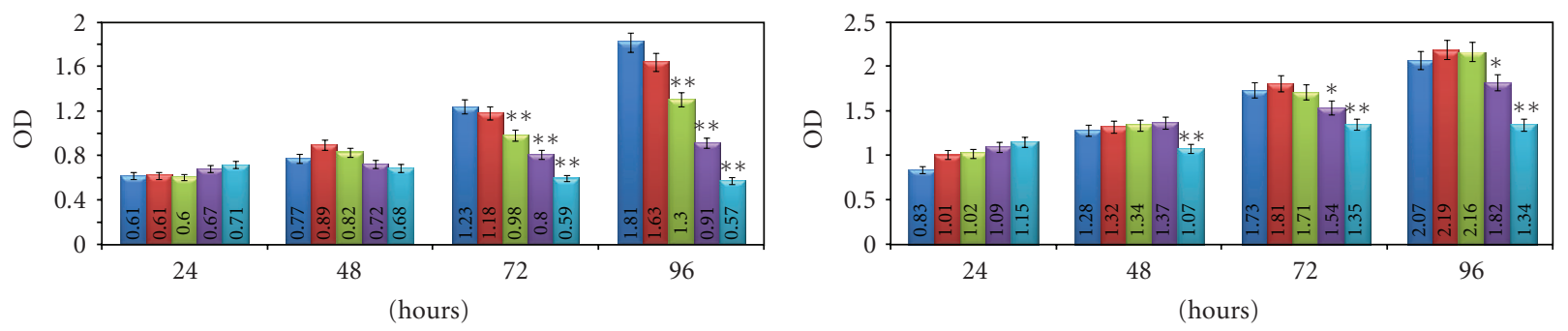

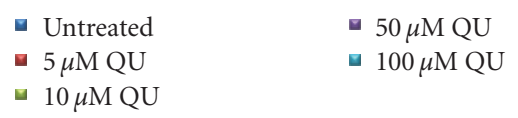

(a)

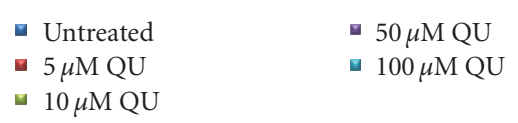

(b)

FIGURE 1: SPC212 (a) and SPC111 (b) cells were cultured and treated with $5 \mu \mathrm{M}$ QU, $10 \mu \mathrm{M}$ QU, $50 \mu \mathrm{M}$ QU, and $100 \mu \mathrm{M}$ QU for 0-96 hours. Applications of QU $>10 \mu \mathrm{M}$ and QU $\geq 50 \mu \mathrm{M}$ caused reduction of cell numbers in SPC212 and SPC111 cells at 72 hours, respectively. Data was statistically evaluated between control group and multiple dose groups of QU, with the level of significance chosen as ${ }^{*} P<.05$ and ${ }^{* *} P<.01$.

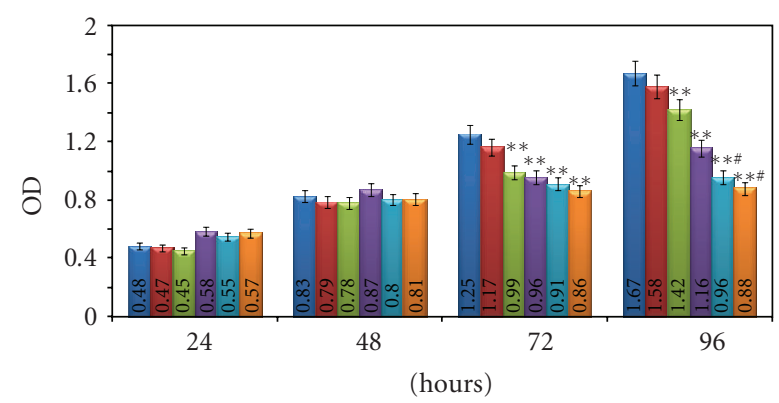

- Untreated
- $5 \mu \mathrm{g} / \mathrm{mL}$ CIS
- $10 \mu \mathrm{g} / \mathrm{mL}$ CIS

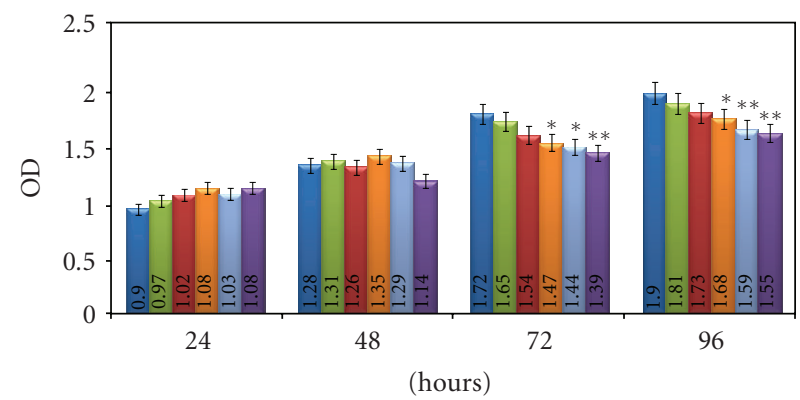

Untreated
- $5 \mu \mathrm{g} / \mathrm{mL} \mathrm{CIS}$
- $10 \mu \mathrm{g} / \mathrm{mL} \mathrm{CIS}$
- $50 \mu \mathrm{M} \mathrm{QU}$

- $5 \mu \mathrm{g} / \mathrm{mL}$ CIS $+50 \mu \mathrm{M}$ QU

घ $10 \mu \mathrm{g} / \mathrm{mL} \mathrm{CIS}+50 \mu \mathrm{M} \mathrm{QU}$

(a)

(b)

FIgURE 2: SPC212 (a) and SPC111 (b) cells were untreated and treated with $5 \mu \mathrm{g} / \mathrm{ml} \mathrm{CIS,} 10 \mu \mathrm{g} / \mathrm{mL}$ CIS, $50 \mu \mathrm{M}$ QU and $5 \mu \mathrm{g} / \mathrm{mL}$ CIS + $50 \mu \mathrm{MQU}$, and $10 \mu \mathrm{g} / \mathrm{mL}$ CIS $+50 \mu \mathrm{M}$ QU for 0-96 hours. Cell proliferation decrease imposed by QU, CIS, and QU + CIS was time dependent. Combination treatments were found more effective than individual treatments in SPC212 cells in 96 hours (a). Additionally, both individual and combination applications reduced cell proliferation in SPC111 cells when compared with untreated cells in 96 hours (b); however no significant differences were observed on the reduction of cell proliferation when compared with combined and individual treatments in 96 hours. Data was statistically evaluated between control group, single dose groups, and combination dose groups, with the level of significance chosen as ${ }^{*} P \leq .05 ;{ }^{*} P \leq .01$, and ${ }^{*} P<.05$ between QU + CIS treatment and CIS alone.

different from individual treatments in SPC111 cells (Figures $3(\mathrm{a}), 3(\mathrm{~b}), 3(\mathrm{c})$, and $3(\mathrm{~d}))$.

3.3. Effect of Treatments on C3 and C9 Activity. Both cell lines were treated with $5 \mu \mathrm{g} / \mathrm{mLCIS}+50 \mu \mathrm{MQU}$ and $10 \mu \mathrm{g} / \mathrm{mLCIS}+50 \mu \mathrm{MQU}$ in combination as well as individually. Caspase activities were measured after drug treatments at 24 and 48 hours. Increased C9 activity was observed in SPC212 compared to the control cells and the cells treated with single doses of $5,10 \mu \mathrm{g} / \mathrm{mL}$ CIS, and $50 \mu \mathrm{M}$ QU at $48 \mathrm{~h}$. Additionally $5 \mu \mathrm{g} / \mathrm{mL}$ CIS $+50 \mu \mathrm{M}$ QU and $10 \mu \mathrm{M}$ CIS $+50 \mu \mathrm{M}$ QU significantly raised C9 activation when compared with individual treatments at 48 hours ( $\left.{ }^{\# \# \#} P<.05\right)$ (Figure $4($ a) ). Increased C3 activation was also detected in SPC212 cell lines at the same concentration of drugs individually and in combination for 48 hours (Figure 4(b)). Interestingly, $10 \mu \mathrm{g} / \mathrm{mL}$ CIS + $50 \mu \mathrm{M}$ QU applications activated both caspases at 24 hours (Figures 4(a) and 4(b)). On the contrary, SPC111 cell lines showed different profile on caspase activation. No C9 activation was observed with individual doses of agents but only $10 \mu \mathrm{g} / \mathrm{mLCIS}+50 \mu \mathrm{M}$ QU applications activated C9 (Figure 4(c)). As shown in Figure 4(d) neither single nor combined treatments activated C3 in SPC111 cells.

\section{Discussion}

In this paper, we have investigated the effects of the QU molecule alone and in combination with a chemotherapeutic agent, CIS, on two MM cell lines. Antiproliferative action of 


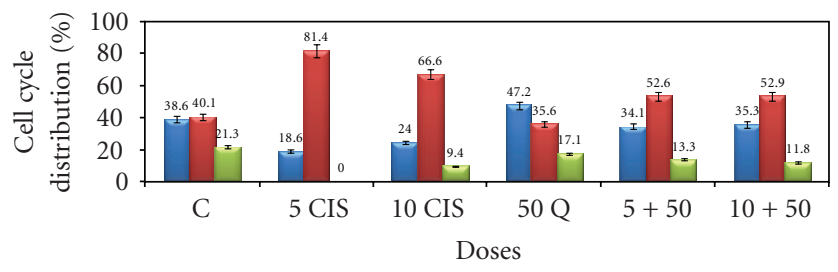

(a)

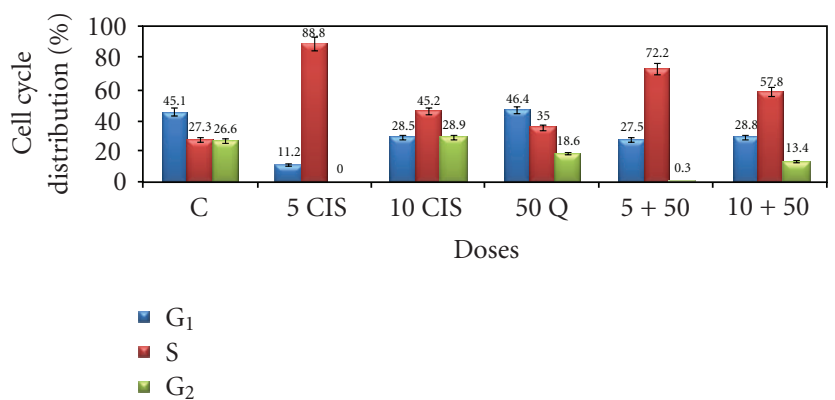

(c)

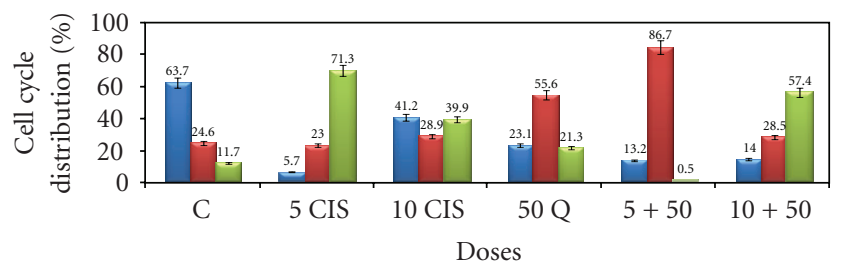

(b)

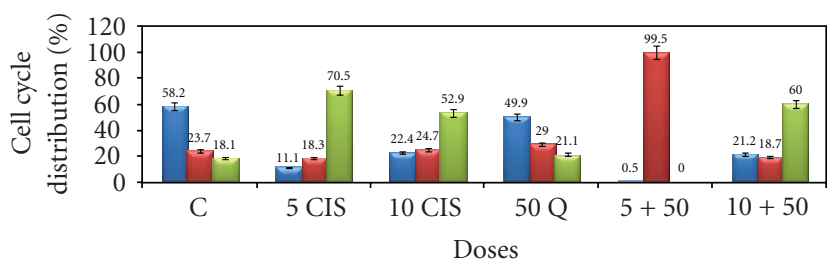

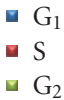

FIgURE 3: SPC212 cells ((a) and (b)) and SPC111 cells ((c) and (d)) were untreated, treated with $5 \mu \mathrm{g} / \mathrm{mL}$ CIS, $10 \mu \mathrm{g} / \mathrm{mL}$ CIS, $50 \mu \mathrm{M} \mathrm{QU}$, and combination of both at 24 hours ( (a) and (c)) and 48 hours ((b) and (d)). Accumulation of cells in S phase was detected in SPC212 but not in SPC111 cells following QU treatments for 48 hours ((b) and (d)). However, individual CIS applications resulted in accumulation of both cells in S phase at the first 24 hours period ((a) and (c)), and cells were arrested at $\mathrm{G}_{2} / \mathrm{M}$ phase in the following 24 hours ((b) and (d)). Distribution of cell cycle was altered in both cells with $5 \mu \mathrm{g} / \mathrm{mL} \mathrm{CIS}+50 \mu \mathrm{M}$ QU treatment compared with untreated cells and cells were treated with individual agents. The percentage of S phase arrest was observed as $86.7 \%$ in SPC212 and $99 \%$ in SPC111 cells, at 48 hours ((b) and (d)). On the other hand, cells treated with $10 \mu \mathrm{g} / \mathrm{mL}$ CIS $+50 \mu \mathrm{M}$ QU showed a similar profile to that of individual $10 \mu \mathrm{g} / \mathrm{mL}$ CIS dose applications in SPC111 cells ((c) and (d)).

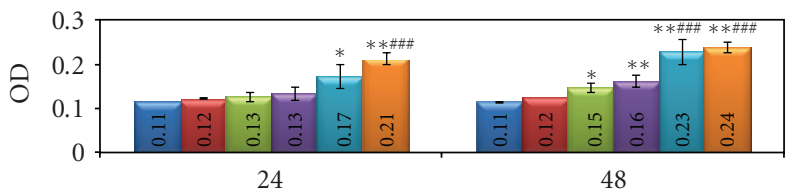

(hours)

(a)

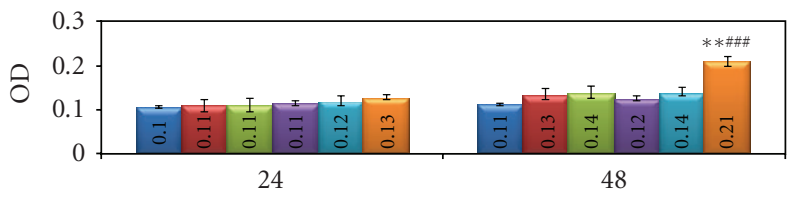

(hours)

$$
\begin{aligned}
& \text { - Untreated } \\
& \text { - } 5 \mu \mathrm{g} / \mathrm{mL} \mathrm{CIS}
\end{aligned}
$$$$
\text { - } 10 \mu \mathrm{g} / \mathrm{mL} \text { CIS }
$$

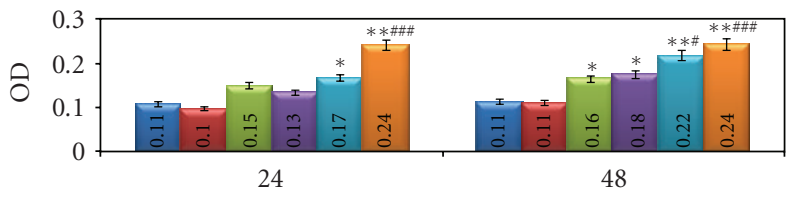

(hours)

(b)

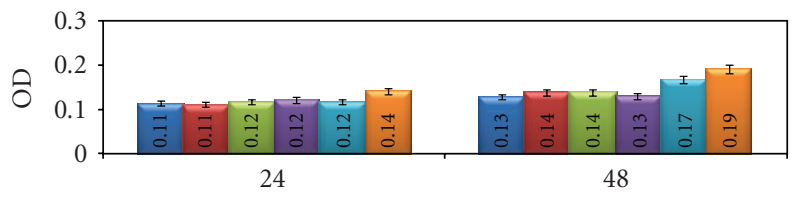

(hours)
- $50 \mu \mathrm{MQU}$

- $5 \mu \mathrm{g} / \mathrm{mL}$ CIS $+50 \mu \mathrm{M} \mathrm{QU}$

- $10 \mu \mathrm{g} / \mathrm{mL}$ CIS $+50 \mu \mathrm{M}$ QU

(d)

Figure 4: SPC212 ((a) and (b)) and SPC111 cells ((c) and (d)) were treated with $5 \mu \mathrm{g} / \mathrm{mL} \mathrm{CIS,} 10 \mu \mathrm{g} / \mathrm{mL}$ CIS, $50 \mu \mathrm{M}$ QU, $5 \mu \mathrm{g} / \mathrm{mL}$ CIS + $50 \mu \mathrm{M} \mathrm{QU}$, and $10 \mu \mathrm{g} / \mathrm{mL}$ CIS $+50 \mu \mathrm{M}$ QU for 48 hours. C9 ((a) and (c)) and C3 ((b) and (d)) activities were measured as indicated in Section 2.5 compared to control and single agent treatments. $10 \mu \mathrm{g} / \mathrm{mL}$ CIS $+50 \mu \mathrm{M}$ QU combinations activated C9 in both cell lines for 48 hours ((a) and (c)). C9 and C3 activities were increased in SPC212 cells following $10 \mu \mathrm{g} / \mathrm{mL}$ CIS $+50 \mu \mathrm{M}$ QU at 24 hours when compared to the control cells and the cells treated with individual doses of QU and CIS ((a) and (b)). Additionally, $5 \mu \mathrm{g} / \mathrm{mL}$ CIS $+50 \mu \mathrm{M}$ QU combination treatments of SPC212 cells were found effective to activate C9 and C3 molecules at 48 hours ((a) and (b)). In addition C9 was activated with $10 \mu \mathrm{g} / \mathrm{mL}$ CIS $+50 \mu \mathrm{M}$ QU applications on SPC111 cells. However, there was no C3 activity detected in SPC111 cells for 48 hours (d). Data was statistically evaluated between control group, single dose groups and combination dose groups, with the level of significance chosen as ${ }^{*} P \leq .05,{ }^{* *} P \leq .01,{ }^{\#} P<.05$ between QU + CIS treatment and CIS alone, and ${ }^{\#} P<.05$ between QU + CIS treatment and QU alone. 
QU on MM cells was observed in dose- and time-dependent manner.

QU inhibited cell proliferation of SPC212 and SPC111 cells at concentrations of $\mathrm{QU}>10 \mu \mathrm{M}$ and $\mathrm{QU} \geq 50 \mu \mathrm{M}$, respectively (Figures $1(\mathrm{a})$ and $1(\mathrm{~b})$ ). However, we have observed a biphasic effect of QU $<50 \mu \mathrm{M}$. Interestingly, doses less then $50 \mu \mathrm{M}$ of QU treatment increased cell proliferation of SPC111 cells (Figure 1(b)). The dual effect of QU on the cell proliferations has been previously described in human oral cancer cells, SCC-25 [30], colon carcinoma (HCT116 and HT-29), and mammary adenocarcinoma cell lines (MCF-7) [31]. Moreover, the protective effect at low concentrations and the cytotoxic effects at high concentrations $(\mathrm{QU} \geq 50 \mu \mathrm{M})$ were indicated in rat cells [32]. These results suggest that related to the utilised dose QU works differently in the same cells. Furthermore, QU actions were also found to be cell selective. As indicated in [33], QU inhibited growth of aggressive PC-3 cells and DU145 prostate cancer cells but was not effective on poorly aggressive LNCaP prostate cancer and normal BG-9 fibroblasts. Our results indicate that QU applications caused reduction of cell numbers in both SPC212 and SPC111 cells. Additionally, SPC212 cells were affected by QU at lower doses compared to that of SPC111 suggesting the former cells were more sensitive to QU treatments.

Mesothelial cells were found to be intrinsically resistant to CIS [27], and CIS + QU in combination appear to have enhanced antiproliferative effect in leukaemia and human laryngeal cells [29]. Therefore, combination experiments were performed to investigate whether addition of QU to CIS enhanced anti-proliferative activity on MM cells. Our experiments indicate that combined QU + CIS applications were much more effective to inhibit cell proliferation than using agents individually (Figures 2(a) and 2(b)).

The effect of QU on the cell cycle distributions was pointed out in various cells including $G_{1} / S$ transition in gastric cancer and human leukemic $T$ cells [14] and $\mathrm{G}_{2} / \mathrm{M}$ block in nononcogenic fibroblast, laryngeal, breast, and human acute leukaemia cancer cell lines [18-20]. In our experiments, applications of $50 \mu \mathrm{MQU}$ resulted in $\mathrm{S}$ phase arrest in SPC212 cells (Figures 3(a) and 3(d)) but not in SPC111 cells (Figures 3(c) and 3(d)). In addition, $5 \mu \mathrm{g} / \mathrm{mLCIS}+50 \mu \mathrm{MQU}$ treatments accumulated both cells in $S$ phase and there were no transition to $G_{2} / M$ phase between 24 and 48 hours (Figures 3(a), 3(b), 3(c), and $3(\mathrm{~d}))$. These results might suggest the existence of enhanced antiproliferative effect due to CIS + QU working in combination. However, when CIS dose was increased to $10 \mu \mathrm{g} / \mathrm{mL}$ and applied with $50 \mu \mathrm{MQU}$, the combination effect was not different from individual treatments in SPC111 cells (Figures 3(c) and 3(d)).

Several groups demonstrated that treatment with QU causes apoptosis [19-25, 34, 35]. QU leads to activation of C3 in HPB-ALL [36], HT-29 colon cancer cells [37], and pancreatic cells [34], C3 and C9 activation in HL-60 [38], and C3, C7, and C9 activation in A549 lung cancer cells [22]. In our experiments, C9 and C3 activation in SPC212 (Figures 4(a) and 4(b)) and C9 activation in SPC111 cells were observed (Figure 4(c)), indicating that apoptosis was induced by QU. The effect of QU was found to be time and dose dependent.

The enhanced effect of QU on CIS was reported in human laryngeal Hep2 cells. 2, $5 \mu \mathrm{g} / \mathrm{mLCIS}+40 \mu \mathrm{MQU}$ induced apoptosis and increased C9 and C8 activity [39]. In addition, $10 \mu \mathrm{g} / \mathrm{mLCIS}+15 \mu \mathrm{g} / \mathrm{mL}$ QU enhanced the proapoptotic effect of HeLa cells through strong activation of C3 [28]. It is also reported that QU inhibits growth of several cancer cell lines where anti-proliferative activity was mediated by Type II Estrogen-Binding Sides (Type II EBS) $[40,41]$. Furthermore, it is suggested that QU may synergize with CIS by interaction with these binding sites [41, 42]. We observed that QU alone and in combination with CIS activated C9 and C3 in SPC212 cells. Activation level of caspases was significantly increased by combine treatments when compared with individual agents (Figures $4(a)$ and $4(\mathrm{~b})$ ).

Although similar experiments were performed in different cancer cells, to our best knowledge, this is the first report investigating anti-proliferative activity of QU and QU + CIS partnership on MM cells in vitro. QU alone and together with CIS have an anti-proliferative potential on MM cells by reducing cell proliferation and altering the cell cycle profile of both cells. In addition, C9 and C3 activations were observed, indicating that apoptosis induced by agents alone and in combination.

The interaction between QU and CIS might provide an interesting approach to combination therapy of MM. This may allow the use of lower concentration of the chemotherapeutic drug CIS and will also have the benefit of increased efficiency and reduction in side effects and drug resistance.

\section{Acknowledgments}

This work was supported by grant TBAG 2336 103T-145 from Turkish Scientific and Technological Research Council of Turkey (TUBITAK). Special thanks to Dr. Pınar Ergenekon (GYTE) for statistical calculation and Dr. Nil Saydan (GYTE) for providing the cell lines.

\section{References}

[1] S. J. Weiner and S. Neragi-Miandoab, "Pathogenesis of malignant pleural mesothelioma and the role of environmental and genetic factors," Journal of Cancer Research and Clinical Oncology, vol. 135, no. 1, pp. 15-27, 2009.

[2] R. Garcia-Carbonero and L. Paz-Ares, "Systemic chemotherapy in the management of malignant peritoneal mesothelioma," European Journal of Surgical Oncology, vol. 32, no. 6, pp. 676-681, 2006.

[3] J. Green, Y. Dundar, S. Dodd, R. Dickson, and T. Walley, "Pemetrexed disodium in combination with cisplatin versus other cytotoxic agents or supportive care for the treatment of malignant pleural mesothelioma," Cochrane Database of Systematic Reviews, no. 1, Article ID CD005574, 2007.

[4] A. Y. Lee, D. J. Ras, B. He, and D. M. Jablons, "Update on the molecular biology of malignant mesothelioma," Cancer, vol. 109, no. 8, pp. 1454-1461, 2007. 
[5] J. Dowell, R. Taub, C. Lan., et al., "A multicenter phase II study of pemetrexed, cisplatin, and bevacizumab in patients with advanced malignant mesothelioma," Journal of Clinical Oncology, vol. 27, no. 15S, p. 401s, 2009, Abstr. 7578.

[6] G. Pasello and A. Favaretto, "Molecular targets in malignant pleural mesothelioma treatment," Current Drug Targets, vol. 10, no. 12, pp. 1235-1244, 2009.

[7] G. L. Russo, "Ins and outs of dietary phytochemicals in cancer chemoprevention," Biochemical Pharmacology, vol. 74, no. 4, pp. 533-544, 2007.

[8] S. K. Jaganathan and M. Mandal, "Antiproliferative effects of honey and of its polyphenols: a review," Journal of Biomedicine and Biotechnology, vol. 2009, Article ID 830616, 13 pages, 2009.

[9] T.-B. Kang and N.-C. Liang, "Studies on the inhibitory effects of quercetin on the HL-60 leukemia cells," Biochemical Pharmacology, vol. 54, no. 9, pp. 1013-1018, 1997.

[10] J. A. Choi, J. Y. Kim, J. Y. Lee, et al., "Induction of cell cycle arrest and apoptosis in human breast cancer cells by quercetin," International Journal of Oncology, vol. 19, no. 4, pp. 837-844, 2001.

[11] M. Salucci, L. A. Stivala, G. Maiani, R. Bugianesi, and V. Vannini, "Flavonoids uptake and their effect on cell cycle of human colon adenocarcinoma cells (Caco2)," British Journal of Cancer, vol. 86, no. 10, pp. 1645-1651, 2002.

[12] T. Kobayashi, T. Nakata, and T. Kuzumaki, "Effect of flavonoids on cell cycle progression in prostate cancer cells," Cancer Letters, vol. 176, no. 1, pp. 17-23, 2002.

[13] M. Kaneuchi, M. Sasaki, Y. Tanaka, N. Sakuragi, S. Fujimoto, and R. Dahiya, "Quercetin regulates growth of Ishikawa cells through the suppression of EGF and cyclin D1," International Journal of Oncology, vol. 22, no. 1, pp. 159-164, 2003.

[14] M. Yoshida, M. Yamamoto, and T. Nikaido, "Quercetin arrests human leukemic T-cells in late G1 phase of the cell cycle," Cancer Research, vol. 52, no. 23, pp. 6676-6681, 1992.

[15] M. A. Avila, J. A. Velasco, J. Cansado, and V. Notario, "Quercetin mediates the down-regulation of mutant p53 in the human breast cancer cell line MDA-MB468," Cancer Research, vol. 54, no. 9, pp. 2424-2428, 1994.

[16] G. Ferrandina, G. Almadori, N. Maggiano, et al., "Growthinhibitory effect of tamoxifen and quercetin and presence of type II estrogen binding sites in human laryngeal cancer cell lines and primary laryngeal tumors," International Journal of Cancer, vol. 77, no. 5, pp. 747-754, 1998.

[17] E. J. Choi, S. M. Bae, and W. S. Ahn, "Antiproliferative effects of quercetin through cell cycle arrest and apoptosis in human breast cancer MDA-MB-453 cells," Archives of Pharmacal Research, vol. 31, no. 10, pp. 1281-1285, 2008.

[18] G. Rusak, H. O. Gutzeit, and J. L. Müller, "Structurally related flavonoids with antioxidative properties differentially affect cell cycle progression and apoptosis of human acute leukemia cells," Nutrition Research, vol. 25, no. 2, pp. 143-155, 2005.

[19] S. U. Mertens-Talcott and S. S. Percival, "Ellagic acid and quercetin interact synergistically with resveratrol in the induction of apoptosis and cause transient cell cycle arrest in human leukemia cells," Cancer Letters, vol. 218, no. 2, pp. 141-151, 2005.

[20] F. Hakimuddin, G. Paliyath, and K. Meckling, "Selective cytotoxicity of a red grape wine flavonoid fraction against MCF-7 cells," Breast Cancer Research and Treatment, vol. 85, no. 1, pp. 65-79, 2004.

[21] M. M. Chan, D. Fong, K. J. Soprano, W. F. Holmes, and H. Heverling, "Inhibition of growth and sensitization to cisplatin-mediated killing of ovarian cancer cells by polyphenolic chemopreventive agents," Journal of Cellular Physiology, vol. 194, no. 1, pp. 63-70, 2003.

[22] T. T. T. Nguyen, E. Tran, T. H. Nguyen, P. T. Do, T. H. Huynh, and H. Huynh, "The role of activated MEK-ERK pathway in quercetin-induced growth inhibition and apoptosis in A549 lung cancer cells," Carcinogenesis, vol. 25, no. 5, pp. 647-659, 2004.

[23] C. S. Ong, E. Tran, T. T. Nguyen, et al., "Quercetin-induced growth inhibition and cell death in nasopharyngeal carcinoma cells are associated with increase in Bad and hypophosphorylated retinoblastoma expressions," Oncology Reports, vol. 11, no. 3, pp. 727-733, 2004.

[24] M. J. van Erk, P. Roepman, T. R. van der Lende, et al., "Integrated assessment by multiple gene expression analysis of quercetin bioactivity on anticancer-related mechanisms in colon cancer cells in vitro," European Journal of Nutrition, vol. 44, no. 3, pp. 143-156, 2005.

[25] X.-M. Zhang, J. Chen, Y.-G. Xia, and Q. Xu, "Apoptosis of murine melanoma B16-BL6 cells induced by quercetin targeting mitochondria, inhibiting expression of PKC- $\alpha$ and translocating PKC- $\delta$," Cancer Chemotherapy and Pharmacology, vol. 55, no. 3, pp. 251-262, 2005.

[26] C. A. Rabik and M. E. Dolan, "Molecular mechanisms of resistance and toxicity associated with platinating agents," Cancer Treatment Reviews, vol. 33, no. 1, pp. 9-23, 2007.

[27] A. de Cupis, C. Semino, P. Pirani, M. Loprevite, A. Ardizzoni, and R. E. Favoni, "Enhanced effectiveness of last generation antiblastic compounds vs. cisplatin on malignant pleural mesothelioma cell lines," European Journal of Pharmacology, vol. 473, no. 2-3, pp. 83-95, 2003.

[28] J. Jakubowicz-Gil, R. Paduch, T. Piersiak, K. Glowniak, A. Gawron, and M. Kandefer-Szerszen, "The effect of quercetin on pro-apoptotic activity of cisplatin in HeLa cells," Biochemical Pharmacology, vol. 69, no. 9, pp. 1343-1350, 2005.

[29] L. Cipak, P. Rauko, E. Miadokova, I. Cipakova, and L. Novotny, "Effects of flavonoids on cisplatin-induced apoptosis of HL-60 and L1210 leukemia cells," Leukemia Research, vol. 27, no. 1, pp. 65-72, 2003.

[30] T. M. Elattar and A. S. Virji, "The inhibitory effect of curcumin, genistein, quercetin and cisplatin on the growth of oral cancer cells in vitro," Anticancer Research, vol. 20, no. 3A, pp. 1733-1738, 2000.

[31] H. van der Woude, A. Gliszczyńska-Swigło, K. Struijs, A. Smeets, G. M. Alink, and I. M. C. M. Rietjens, "Biphasic modulation of cell proliferation by quercetin at concentrations physiologically relevant in humans," Cancer Letters, vol. 200, no. 1, pp. 41-47, 2003.

[32] W. Wätjen, G. Michels, B. Steffan, et al., "Low concentrations of flavonoids are protective in rat H4IIE cells whereas high concentrations cause DNA damage and apoptosis," Journal of Nutrition, vol. 135, no. 3, pp. 525-531, 2005.

[33] H. K. Nair, K. V. K. Rao, R. Aalinkeel, S. Mahajan, R. Chawda, and S. A. Schwartz, "Inhibition of prostate cancer cell colony formation by the flavonoid quercetin correlates with modulation of specific regulatory genes," Clinical and Diagnostic Laboratory Immunology, vol. 11, no. 1, pp. 63-69, 2004.

[34] M. Mouria, A. S. Gukovskaya, Y. Jung, et al., "Food-derived polyphenols inhibit pancreatic cancer growth through mitochondrial cytochrome C release and apoptosis," International Journal of Cancer, vol. 98, no. 5, pp. 761-769, 2002. 
[35] S. Ramos, M. Alía, L. Bravo, and L. Goya, "Comparative effects of food-derived polyphenols on the viability and apoptosis of a human hepatoma cell line (HepG2)," Journal of Agricultural and Food Chemistry, vol. 53, no. 4, pp. 1271-1280, 2005.

[36] M. Russo, R. Palumbo, I. Tedesco, et al., "Quercetin and antiCD95(Fas/Apo1) enhance apoptosis in HPB-ALL cell line," FEBS Letters, vol. 462, no. 3, pp. 322-328, 1999.

[37] U. Wenzel, A. Herzog, S. Kuntz, and H. Daniel, "Protein expression profiling identifies molecular targets of quercetin as a major dietary flavonoid in human colon cancer cells," Proteomics, vol. 4, no. 7, pp. 2160-2174, 2004.

[38] I.-K. Wang, S.-Y. Lin-Shiau, and J.-K. Lin, "Induction of apoptosis by apigenin and related flavonoids through cytochrome $\mathrm{C}$ release and activation of caspase- 9 and caspase- 3 in leukaemia HL-60 cells," European Journal of Cancer, vol. 35, no. 10, pp. 1517-1525, 1999.

[39] H. Sharma, S. Sen, and N. Singh, "Molecular pathways in the chemosensitization of cisplatin by quercetin in human head and neck cancer," Cancer Biology and Therapy, vol. 4, no. 9, pp. 949-955, 2005.

[40] L. M. Larocca, L. Teofili, G. Leone, et al., "Antiproliferative activity of quercetin on normal bone marrow and leukaemic progenitors," British Journal of Haematology, vol. 79, no. 4, pp. 562-566, 1991.

[41] P. Miodini, L. Fioravanti, G. Di Fronzo, and V. Cappelletti, "The two phyto-oestrogens genistein and quercetin exert different effects on oestrogen receptor function," British Journal of Cancer, vol. 80, no. 8, pp. 1150-1155, 1999.

[42] G. Scambia, F. O. Ranelletti, P. B. Panici, et al., "Quercetin induces type-II estrogen-binding sites in estrogen-receptornegative (MDA-MB231) and estrogen-receptor-positive (MCF-7) human breast-cancer cell lines," International Journal of Cancer, vol. 54, no. 3, pp. 462-466, 1993. 


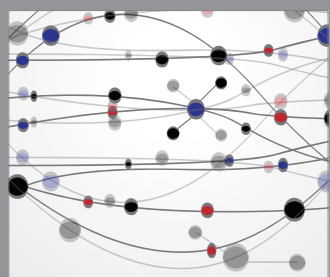

The Scientific World Journal
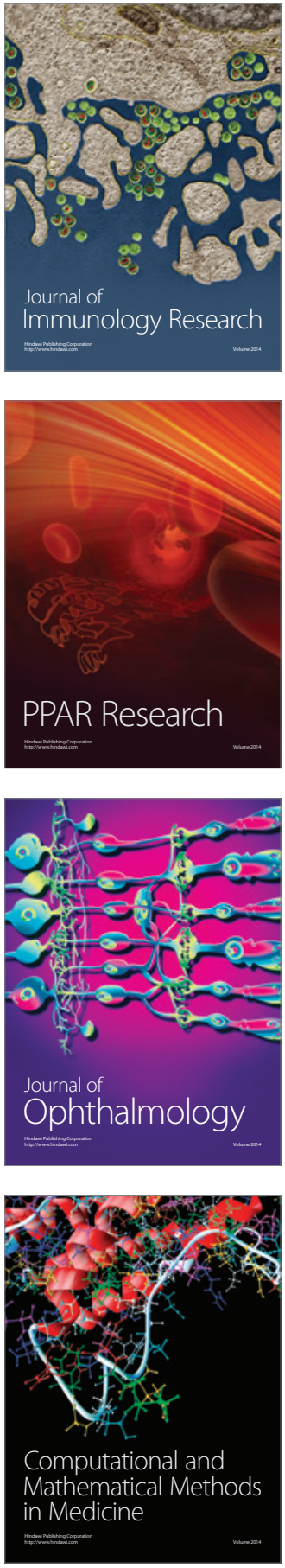

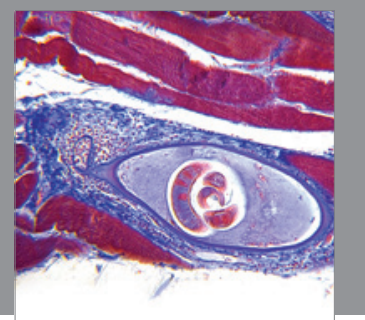

Gastroenterology

Research and Practice
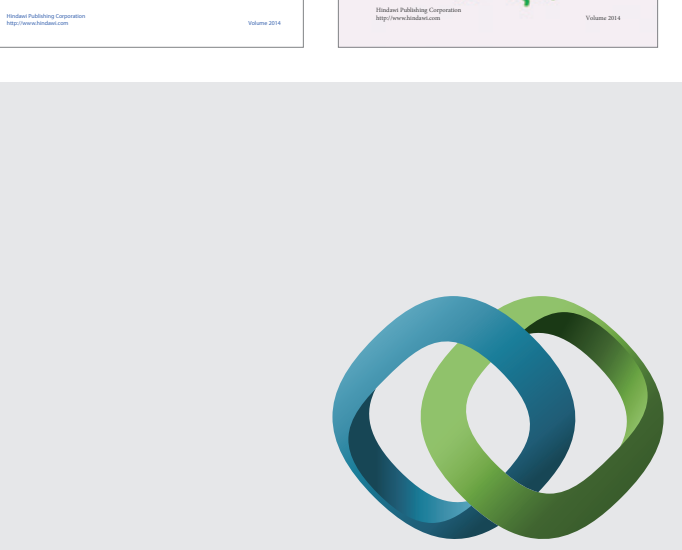

\section{Hindawi}

Submit your manuscripts at

http://www.hindawi.com
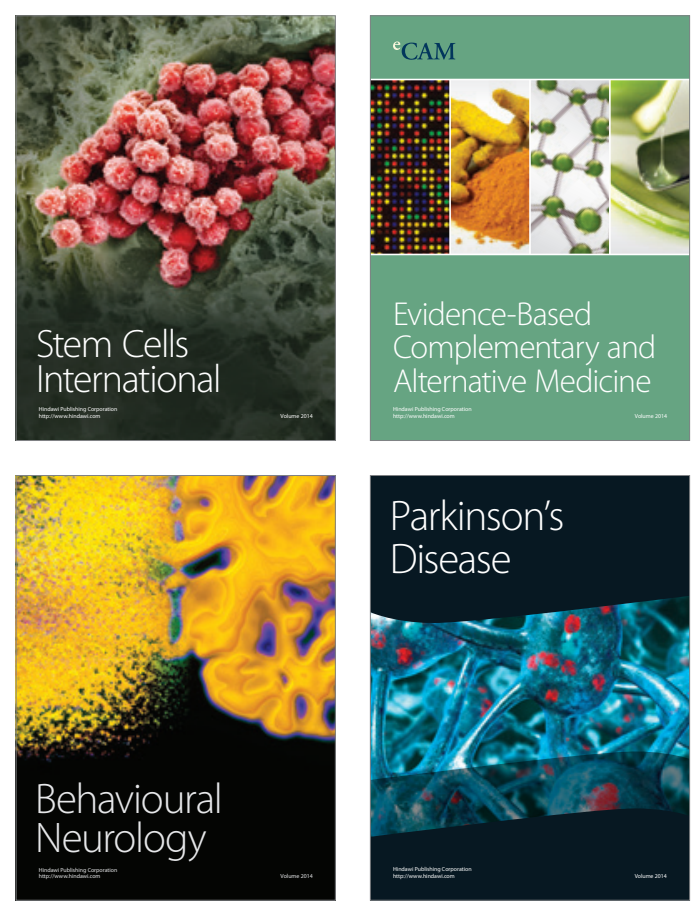

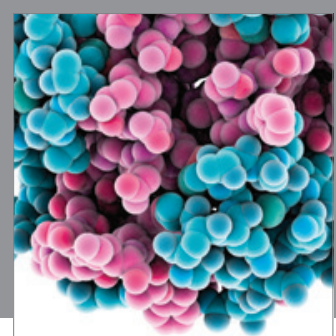

Journal of
Diabetes Research

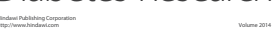

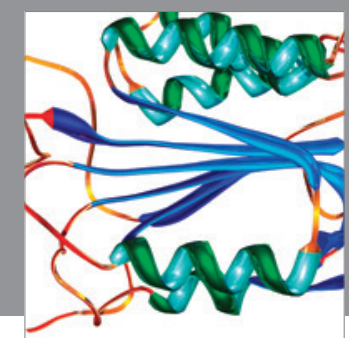

Disease Markers
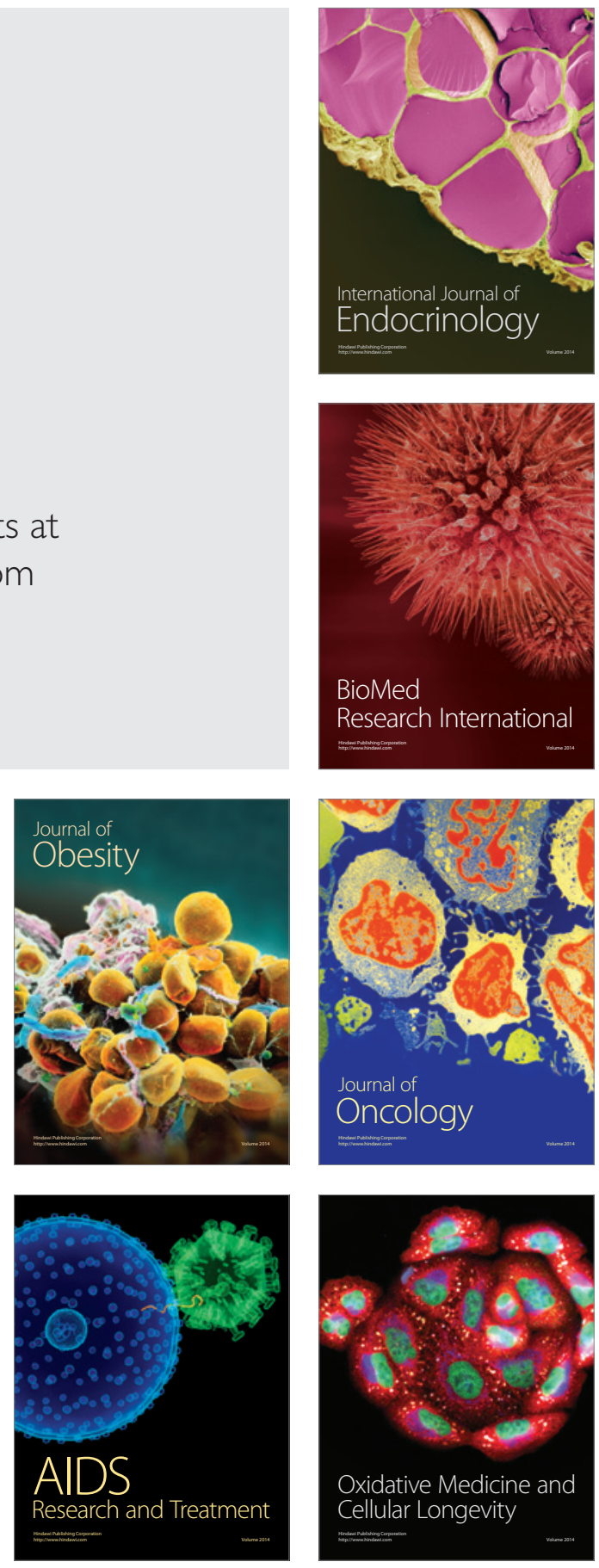